\title{
Development of VLE Frog Website on Pre-Number Topic for Students with Learning Disability
}

\author{
Iklil Kamarul Zaman, Rosadah Abd Majid, Manisah Mohd. Ali, Mahfuzah Zainol \\ Department of Special Education, Faculty of Education, National University of Malaysia, Bangi, Malaysia \\ Email: iklilkamarulzaman@gmail.com
}

How to cite this paper: Zaman, I. K., Majid, R. A., Ali, M. M., \& Zainol, M. (2018). Development of VLE Frog Website on Pre-Number Topic for Students with Learning Disability. Creative Education, 9, 2224-2233.

https://doi.org/10.4236/ce.2018.914163

Received: August 16, 2018

Accepted: October 26, 2018

Published: October 29, 2018

Copyright (c) 2018 by authors and Scientific Research Publishing Inc. This work is licensed under the Creative Commons Attribution International License (CC BY 4.0).

http://creativecommons.org/licenses/by/4.0/

\begin{abstract}
This study is intended to design, develop and evaluate teaching materials based on Frog Virtual Learning Environment (VLE Frog) for Mathematics subject on Pre-Number's topic. The development of this website was based on the ADDIE framework and comprising five phases; analyse, design, development, implement and evaluation. "Jom Belajar Matematik" website was obtained using the VLE Frog platform. Feedback regarding the use of the website was obtained using questionnaires and interviews. Ten special education teachers completed the questionnaires in one of the schools in Sepang. The descriptive and inferential analysis was used to test the research questions using the Statistical Package for the Social Sciences (SPSS) version 22.0. The findings show that there are the overall means of presentation style and content and language are at a very high level, while the overall mean of interest of special education teachers of Mathematics subject in teaching and learning based on "Jom Belajar Matematik" is high. The finding also shows that there is a significant relationship between the levels of interest of Special Education teachers in one of the secondary school in Sepang district based on age. The VLE Frog website of "Jom Belajar Matematik" is accessible at any time, and it is free of charge, via https://bea9604.1bestarinet.net/iklilkamarulzaman.
\end{abstract}

\section{Keywords}

Special Education, Special Needs, Learning Disability, Development, Technology, Website, ADDIE Model, Mathematics, VLE Frog

\section{Introduction}

The use of ICT (Information and Communication Technology) is widespread increasingly, and it is not only focused on the workforce, but it is also wide- 
spread in the education system at schools in Malaysia as well as overseas. However, special education is no exception in the use of ICT as it helps in teaching and learning process in special education schools. According to Arshad (2005), Malaysia is in the process of transforming the education system to achieve the vision of 2020.

Teachers are leaders in school, and they should be more creative and innovative in channelling information and managing their knowledge using technology (Laroiya, 2008). The Malaysian Education Blueprint 2013-2015 which was introduced by the Ministry of Education Malaysia (MOE) has put the ICT benefit goal in teaching and learning. Kementerian Pelajaran Malaysia (2012), calls every student to have access to quality education and the integration of today's technology world.

A study was conducted by Norhayati \& Siew (2004), which showed that the rate of learning and human understanding could be enhanced by using interactive media in a learning environment. Applications and multimedia technologies can be used to improve work efficiency and productivity, provide information at the fingertips for home users and help students learn more effectively inside or outside the classroom (Hillman, 1998). Therefore, interactive multimedia should also be able to serve as a cognitive, collaborative and communication tool by providing a teaching and learning environment that can support, guide and expand the thinking process, especially for special needs students.

A study conducted by Davies \& Graff (2004) which is the use of internet and attitudes towards computers and its relation to the differences in cognitive and cross-cultural styles have shown that attitudes and values towards younger age groups are more positive than those of older groups. Also, the study conducted by Rosnani (2006) has also identified five factors that contribute to ICT skills such as age, ICT experience, ICT course attendance, Internet access at home or at school. Therefore, the age factor also affects the use of technology in learning and teaching.

This study was conducted to answer some questions. Among the questions asked are: 1) How is the interactive website VLE frog for mathematics subject for pre-number topic designed and developed as teaching aids? 2) What is the level of technical presentation style, content and language used in the VLE Frog "Jom Belajar Matemetik" website? 3) What is the level of interest of special education teachers on teaching and learning based on the "Jom Belajar Matemetik" website? 4) Are there differences in the level of interest of special education teachers in one of the high schools in Sepang based on age? And, 5) What are the advantages and disadvantages of teaching and learning based on the VLE Frog "Jom Belajar Matemetik" website from the perspective of special education teachers?. The null hypothesis $\left(\mathrm{H}_{\mathrm{o}}\right)$ for this study is, there is no significant difference in the level of interest of special education teachers in one of the secondary schools in the Sepang district based on age. 


\section{Conceptual Framework}

The framework of this research concept illustrates and describes the construction framework of "Jom Belajar Matematik" website constructed based on the modified design steps from the ADDIE Model which consists of five main phases, namely analysis, design, development, implementation and evaluation. The ADDIE model is an easy-to-use model where the processes used are systematic with clear frameworks that deliver practical, creative, and efficient products (Kamisah, 2010). Figure 1 shows the conceptual framework of the study based on the ADDIE model (Rossett, 1987).

\section{Research Method}

This study is aimed at developing a teaching and learning website for the pre-numbers topic for learning disabilities. This software is expected to assist special education's teachers to diversify teaching and learning methods by providing computer-assisted learning environments. This software is based on the ADDIE model design instruction model, and it is using mixed methods research design which involved quantitative and qualitative methods.

\subsection{Target Group}

This study involves ten special education teachers in one of the secondary school in Sepang by using Special Education High School Curriculum (KSSM). The sampling method used by the researcher is a purposive sampling method. This method is best used to get information directly from the target group while saving time and cost (Sekaran, 2003). Also, according to Ahmad (2010) this method is also able to give an excellent descriptive decision about the study. Descriptive statistics were used to analyse the data obtained from respondents' demographics. Data analysis is done involving frequency and percentage. The summary of the results of the descriptive study is as shown in Table 1.

\subsection{Instrument}

A set of questionnaires adapted from Ahmad (2010) study, Paridon (2008) was developed as a research instrument for obtaining data for this study. There are three (3) divisions in this questionnaire, which are Part A, B and C and have 46 items in total. The questionnaire was distributed online to all study populations, a total of 10 Special Education teachers active in a school in Sepang district. This questionnaire has been distributed online because it can save time and cost of study as well as to target the target group accurately.

Part A is Demographics. This section consists of six (6) items aimed at finding the background of the respondents, gender, age, academic qualifications, the duration of teaching experience, the ICT course and the frequency of implementing teaching and learning based on the "Jom Belajar Matematik" website. In this section, the respondent is required to select only one (1) answer related to 


\section{ADDIE Instructional Design Model} (Rosset 1987)

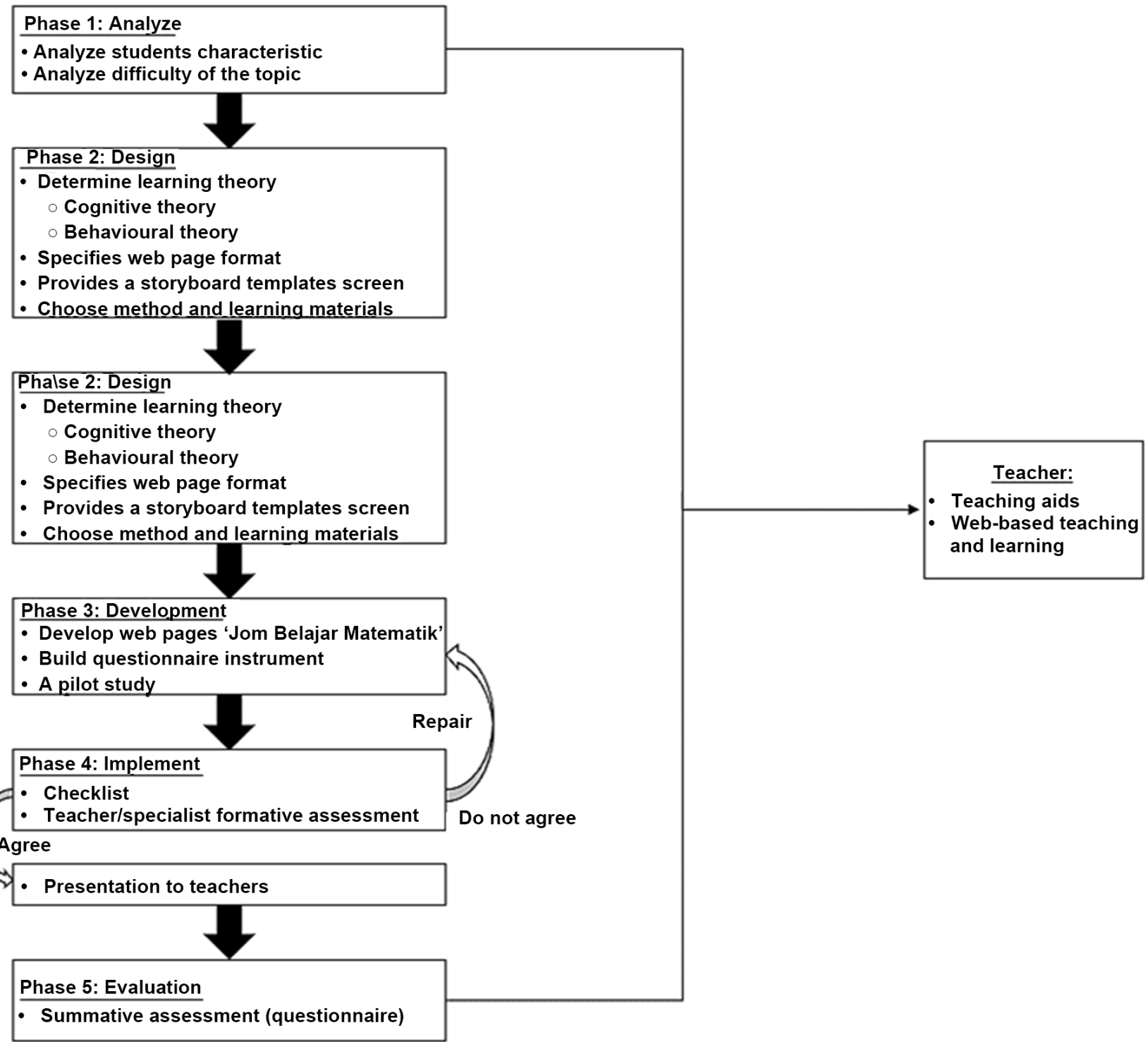

Figure 1. Conceptual framework of the study based on the ADDIE model (Rossett, 1987).

the marking of the appropriate parcel. Part B is comprised of 20 items aimed at assessing technical and language presentation styles consisting of two (2) constructs namely technical presentation and content and language.

While part $\mathrm{C}$ is to measure the interest of the special education teacher of the mathematics subject in teaching and learning based on the "Jom Belajar Matematik" website, comprising 20 items divided into five (5) namely ICT readiness, personal characteristics (self-discipline), sessions learning (self-preparation), learning session (task or homework) and teaching and learning method. Both B and $\mathrm{C}$ sections are answered by respondents using the five-point Likert starting from scale 1 (Strongly Disagree), scale 2 (Disagree), scale 3 (Slightly Agree), scale 4 (Agree), and scale 5 (Strongly Agree) (Kelly, 2008). 
Table 1. Respondent profile summary.

\begin{tabular}{|c|c|c|c|c|}
\hline Code & \multicolumn{2}{|c|}{ Respondent Profile } & $\begin{array}{c}\text { Frequency } \\
(N=10)\end{array}$ & Percentage (\%) \\
\hline \multirow{2}{*}{$\mathrm{A} 1$} & \multirow{2}{*}{ Gander } & Male & 2 & 20 \\
\hline & & Female & 8 & 80 \\
\hline \multirow{4}{*}{ A2 } & \multirow{4}{*}{ Age } & Less than 30 years & 1 & 10 \\
\hline & & $31-40$ years & 4 & 40 \\
\hline & & $41-50$ years & 4 & 40 \\
\hline & & $51-60$ years & 1 & 10 \\
\hline \multirow{2}{*}{$\mathrm{A} 3$} & \multirow{2}{*}{ Academic Qualifications } & Degree/equivalent & 9 & 90 \\
\hline & & Master/equivalent & 1 & 10 \\
\hline \multirow{5}{*}{$\mathrm{A} 4$} & \multirow{5}{*}{$\begin{array}{c}\text { Working Experience } \\
\text { Duration }\end{array}$} & Less than three years & 1 & 10 \\
\hline & & $4-8$ years & 2 & 20 \\
\hline & & $9-16$ years & 4 & 40 \\
\hline & & $17-22$ years & 1 & 10 \\
\hline & & More than 23 years & 2 & 20 \\
\hline \multirow{2}{*}{ A5 } & Ever attended ICT & Yes & 8 & 80 \\
\hline & training & No & 2 & 20 \\
\hline \multirow{2}{*}{ A6 } & Teaching and Learning & Less than 1 hour per week & 4 & 40 \\
\hline & Frequency Using ICT & 2 - 5 hours per week & 6 & 60 \\
\hline
\end{tabular}

\section{Result of the Survey}

\subsection{Technical Presentation Style and Language}

Based on the data analysis as shown in Table 2, the overall mean score for each presentation style and content \& language is $(M=4.30, S . D=0.5838)$. Referring to the interpretation of the min score suggested by Ibrahim \& Don (2014), it is found that the level of technical language and content \& language level is of a very high standard. In the case of the smaller scope, it is found that the first construct of the technical presentation style is at a high level $(\mathrm{M}=4.27, \mathrm{SD}=4.38)$ and the second construct of language $\&$ content is at a very high level $(\mathrm{M}=4.38$, $\mathrm{SD}=0.5846)$.

\subsection{Interest of Special Education Teachers in Mathematic Subject for Web-Based Teaching and Learning}

Based on the data analysis based on Table 3, it was found that the overall mean score for the level of interest in special education teachers of mathematical subjects towards "Jom Belajar Matematik" learning website was $(\mathrm{M}=4.32$, S.D = 0.6223). Referring to the interpretation of the mean score suggested by Ibrahim \& Don (2014), the level of interest of special education teachers of mathematical subjects based on the "Jom Belajar Matematik" website is at a high level. Given the smaller scope, availability of ICT (K1), self-preparation (K3), learning 
Table 2. Mean score level of technical presentation style and language \& content.

\begin{tabular}{ccc}
\hline Construct (K) & Mean Score & Standard Deviation (SD) \\
\hline K1 - Technical presentation style & 4.27 & 0.5951 \\
K2 - Content and language & 4.38 & 0.5846 \\
Total & 4.30 & $\mathbf{0 . 5 8 3 8}$ \\
\hline
\end{tabular}

Table 3. Mean and standard deviation score of interest of special education teachers in web-based teaching and learning "Jom Belajar Matematik".

\begin{tabular}{ccc}
\hline Construct (K) & Mean Score & Standard Deviation \\
\hline K1 - ICT readiness & 4.40 & 0.8097 \\
K2 - Personal characteristics (self-discipline) & 4.28 & 0.6286 \\
K3 - Learning session - self preparation & 4.34 & 0.7059 \\
K4 - Learning session - assignment or homework & 4.23 & 0.6093 \\
K5 - Learning and teaching method & 4.33 & 0.6135 \\
Total & 4.32 & $\mathbf{0 . 6 2 2 3}$ \\
\hline
\end{tabular}

and teaching method (K5) gets the highest mean score. While self-discipline (K2), task or homework (K4) gets a high mean score.

\subsection{Difference Level of Teacher's Interest Based on Age}

Based on one-way ANOVA results as in Table 4, there is a significant difference in the level of interest of special education teachers in one of the secondary schools in the Sepang district based on age $(F(3,6)=5.304 ; p<0.05)$. Therefore, the null hypothesis was rejected that the respondents agreed that there was a significant difference in the level of interest of special education teachers in one of the secondary schools in the Sepang district based on age. Meanwhile at Table 5 is the difference in mean level scores of special education teachers in one of the high schools in Sepang is based on age.

\section{Discussion}

Learning and teaching materials designed and developed are using ADDIE (Technology in Teaching and Learning Technology, 2012). ADDIE is an acronym for Analyze, Design, Development, Implement, and Evaluation. The ADDIE model founded by Rosset in 1987 as a guide in the construction of the 'Jom Belajar Matematik' website. The ADDIE model is a teaching design approach that can be used in any form of development (Branch, 2009). This is because this model is an integration model that provides guidelines and easy methods to follow.

Based on the data analysis for the second research question, the overall mean score for each presentation style and content $\&$ language is $(M=4.30$, S.P $=0.5838)$. Referring to the interpretation of the min score suggested by Ibrahim \& Don (2014), 
Table 4. One-Way ANOVA Test Results to Identify the Difference in The Level of Interest of Special Education Teachers in One of The Secondary Schools in Sepang District Based on Age.

\begin{tabular}{cccccc}
\hline & Sum of Squares & df & Mean Square & F & Sig. \\
\hline Between Groups & 2.531 & 3 & 0.844 & 5.304 & 0.040 \\
Within Groups & 0.954 & 6 & 0.159 & & \\
Total & 3.485 & 9 & & & \\
\hline
\end{tabular}

Table 5. Difference in mean level scores of special education teachers in one of the high schools in sepang based on age.

\begin{tabular}{ccccccccc}
\hline Age & N & Mean & $\begin{array}{c}\text { Std. } \\
\text { Deviation }\end{array}$ & Std. Error & $\begin{array}{c}\text { 95\% Confidence } \\
\text { Interval for Mean }\end{array}$ & Min & Max \\
Bownd & $\begin{array}{c}\text { Upper } \\
\text { Bound }\end{array}$ & & \\
\hline Less than 30 years & 1 & 4.65 &. &. &. &. & 4.65 & 4.65 \\
$31-40$ years & 4 & 4.58 & 0.4873 & 0.2437 & 3.80 & 5.35 & 3.90 & 5.00 \\
$41-50$ years & 4 & 4.34 & 0.2840 & 0.1420 & 3.90 & 4.79 & 4.05 & 4.65 \\
$51-60$ years & 1 & 2.85 &. &. &. &. & 2.85 & 2.85 \\
Total & 10 & 4.32 & $\mathbf{0 . 6 2 2 3}$ & $\mathbf{0 . 1 9 7 0}$ & $\mathbf{3 . 8 7}$ & $\mathbf{4 . 7 6}$ & $\mathbf{2 . 8 5}$ & $\mathbf{5 . 0 0}$ \\
\hline
\end{tabular}

it is found that the level of technical language and content \& language level is at a very high level. In the case of the smaller scope, it is found that the first construct of the technical presentation style is at a high level $(\mathrm{M}=4.27, \mathrm{SP}=4.38)$ and the second construct of language \& content is at a very high level $(M=4.38$, $\mathrm{SP}=0.5846)$. The hypermedia aspect of multimedia plays an important role in education as it allows students to explore a topic according to individual needs and needs. It can be concluded that the use of this multimedia technology enables information to be accessed and used in time and place set by students themselves (dan Zaidatun, 2003).

Based on the data analysis for the third research question, it was found that the overall min score for the level of interest in special education teachers of mathematics subject towards learning and teaching based on the "Jom Belajar Matematik" website was $(\mathrm{M}=4.32$, S.P $=0.6223)$. Characteristics of the special education teacher's interest in both elements of ICT preparation and self-discipline are at a very high and high level. Saunders, Smagner, \& Saunders (2003) found that web-based teaching and learning approaches are more user-friendly and able to attract students as these web-based learning can meet the needs of student learning resources.

Based on the one-way ANOVA for the fourth research question, there is a significant difference in the level of interest of special education teachers in one of the secondary schools in the Sepang district based on age $(F(3,6)=5.304 ; \mathrm{p}<$ $0.05)$. Therefore, the null hypothesis was rejected that the respondents agreed that there was a significant difference in the level of interest of special education 
teachers in one of the secondary schools in the Sepang district based on age. The findings of this study can be attributed to the results of the study conducted by (Davies \& Graff, 2004), which is the use of internet and attitudes towards computers and its relation to the differences in cognitive and cross-cultural styles have shown that attitudes and values towards younger age groups are more positive than those of older groups. In addition, the study conducted by Rosnani (2006) has also identified five factors that contribute to ICT's ICT skills such as age, ICT experience, ICT course attendance, Internet access at home or at school.

An interview was conducted to answer the research question number five. The strength of the fifth research question is, the website contains a user-friendly main menu. There are six (6) main screens contained in this site, an introduction screen, a note screen, a training screen, a game screen, a video screen and a reference screen. According to Barret (1992), multimedia is a combination of audio and visual materials to enhance communication and enriching a presentation. Baharuddin \& Bilal (1995) explain that multimedia is the latest information technology that allows the integration and manipulation of video, audio, text, graphics and animation. Secondly, screen design, presentation style, colour and hypermedia and learning and teaching material based on "Jom Belajar Matematik" website is consistent, attractive and works well. Therefore, the users of the website can maximise the use of the website and can concentrate on teaching.

Thirdly, the site is also flexible, whereas teachers and students can easily use information on the website. According to Reindhart (1995), the combination of visual and auditory senses can increase the memory rate by 50 percent. This is evident when interactive multimedia is effective in shaping and maintaining information over a longperiod, and it can also be achieved in a shorter time when compared to traditional methods (Hofstter \& Komiya, 2000). Meanwhile, the weakness of the "Jom Belajar Matematik" website from a technical point of view is the design of the home screen as the colours and pictures may be too bright and unsuitable for some students. This is inevitable because researchers are not experts in website development. Also, the access to content process is slow due to the size of video files, large documents.

\section{Conclusion}

The VLE Frog "Jom Belajar Matematik" website can be used as a reference source for teachers and special education students in particular and the learning session in the classroom will be more interesting and not just involve one-way interaction. This is because teachers can interact with students unlimitedly and can assist in the teaching and learning process in the classroom. In conclusion, the use of VLE Frog can provide teachers with the opportunity to utilise the technology in their learning and teaching and to improve the quality of teaching practices effectively. The construction of the VLE Frog "Jom Belajar Matematik" website has its challenges. However, to fulfill MOE's intention to implement 
technology-based education at school teachers should be willing to accept these changes. Accordingly, studies related to this field should be continued in different aspects. Among the proposed follow-up ideas are as follows:

1) This study was conducted only involving Special Education teachers in one of the schools in Sepang alone. In this regard, a further study is proposed involving special education teachers in the state of Selangor.

2) This study selects locations in urban areas that have good computer access and internet access. For further studies, it is recommended that the location of the study be conducted in rural and urban areas to assess the ability of teachers in two different locations by applying VLE Frog's web-based learning.

3) The study suggests that special education teachers make the VLE Frog a key platform in the delivery of learning in schools to respond to the ministry's call as in PPPM.

\section{Conflicts of Interest}

The authors declare no conflicts of interest regarding the publication of this paper.

\section{References}

Ahmad, J. (2010). The Importance of Public Relations Education to the Development of the Public Relations Profession in Malaysia. Communication Journal, 1, 73-81.

Arshad, M. (2005). Penggunaan Teknologi Dalam Pendidikan Literasi Bahasa Melayu. Kuala Lumpur: Skudai.

Baharuddin, \& Bilal, M. B. (1995). Pendekatan Alternatif Pengajaran dan Pembelajaran Matematik. Persidangan Kebangsaan Pendidikan Matematik Ke-4, Kuantan, Bahagian Pendidikan Guru, KPM.

Barret (1992). Interactive Learning and Technology in the US Science and Mathematics Reform Movement. British Journal of Educational Technology, 27, 123-133.

Branch, R. M. (2009). Instructional Design: The ADDIE Approach. New York, NY: Springer. https://doi.org/10.1007/978-0-387-09506-6

dan Zaidatun, J. (2003). Reka Bentuk Perisian Multimedia Pendidikan. Skudai: Universiti Teknologi Malaysia.

Davies, J., \& Graff, M. (2004). Performance in E-Learning: Online Participation and Student Grades. British Journal of Educational Technology, 36, 657-663. https://doi.org/10.1111/j.1467-8535.2005.00542.x

Hillman (1998). Proceedings of the 2nd International Educational Technology Convention (pp. 115-120). Kuala Lumpur: META.

Hofstter, N., \& Komiya (2000). Multimedia Literacy. New York, NY: McGraw-Hill.

Ibrahim, I., \& Don, Y. (2014). Kepimpinan Servant dan Pengaruhnya Terhadap Pengurusan Perubahan di Sekolah. Jurnal Pendidikan Malaysia, 39, 19-26.

Kamisah, R. O. (2010). Construction of Interactive Multimedia Modules with Pedagogical agents (IMMPA) in Learning Electrochemistry: Analysis of Needs. Paper Presented at Prosiding Kolokium Kebangsaan Pasca Siswazah Sains and Matematik, Tanjung Malim: Universiti Pendidikan Sultan Idris.

Kelly, S. M. (2008). Correlates of Assistive Technology Use by Students Who Are Visually 
Impaired in the U.S.: Multilevel Modelling of the Special Education Elementary Longitudinal Study. Unpublished Dissertation, DeKalb IL: Northern Illinois University.

Kementerian Pelajaran Malaysia (2012). Laporan Awal Pelan Pembangunan Pendidikan Malaysia 2013-2025. Kuala Lumpur: Kementerian Pelajaran Malaysia.

Laroiya, S. P. B. (2008). Challenges in Preparing Technical Teacher of Tomorrow. Proceedings of 2008 International Conference.

Norhayati, A. M., \& Siew, P. H. (2004). Malaysian Perspective: Designing Interactive Multimedia Learning Environment for Moral Values Education. Educational Technology \& Society, 7, 143-152.

Paridon (2008). Penggunaan ICT Dalam Pengajaran di Sekolah. ICT dalam Pendidikan dan Latihan: Trend dan Isu. Kuala Lumpur: Persatuan Teknologi Pendidikan Malaysia.

Reindhart (1995). Teachers' Use of Educational Technology in US Public Schools. Washington DC: National Center for Education Statistics, Institute of Education Sciences, US Department of Education.

Rosnani (2006). Philosophy in Schools in the Malaysian Context. Conference on Philosophy in Schools: Developing a Community of Inquiry.

Rossett, A. (1987). Training Needs Assessment. Englewood Cliffs, NJ: Educational.

Saunders, M. D., Smagner, J. P., \& Saunders, R. R. (2003). Improving Methodological and Technological Analyses of Adaptive Switch Use of Individuals with Profound Multiple Impairments. Behavioural Interventions, 18, 227-243. https://doi.org/10.1002/bin.141

Sekaran, U. (2003). Business Research Methods. Hoboken, NJ: John Wiley \& Sons. 